\title{
DEOXYRIBONUCLEIC ACID RELATEDNESS AMONG SOME SPORE-FORMING LACTIC ACID BACTERIA
}

\author{
FUJITOSHI YANAGIDA, KEN-ICHIRO SUZUKI, * TAKICHI KANEKO, \\ MICHIO KOZAKI. AND KAZUO KOMAGATA** \\ Department of Agricultural Chemistry, Tokyo University of Agriculture, \\ Setagaya-ku, Tokyo 156, Japan \\ *Japan Collection of Microorganisms, RIKEN, \\ Wako, Saitama 351-01, Japan \\ **Institute of Applied Microbiology, The University of Tokyo, \\ Bunkyo-ku, Tokyo 113, Japan
}

(Received December 1, 1986)

\begin{abstract}
We studied the DNA base composition and DNA-DNA hybridization of 41 strains of spore-forming, lactic acid-producing bacteria including Sporolactobacillus inulinus. The DNA base composition of 41 strains studied ranged from 42.4 to $50.2 \mathrm{~mol}^{\%}$ guanine plus cytosine. The DNA of $S$. inulinus NRIC $1133^{\mathrm{T}}$ showed extremely low homology ( 1 to $5 \%$ ) to the strains of Lactobacillus plantarum and Bacillus coagulans, but it showed somewhat higher homology to "Bacillus laevolacticus," "Bacillus racemilacticus," "Sporolactobacillus laevas," "Sporolactobacillus laevas var. intermedius," and "Sporolactobacillus racemicus" (20-50\%). Catalase-negative strains of spore-forming lactic acid bacteria, including the type strain of $S$. inulinus, showed relatively high homology values to one another and further divided into five groups and considered to be members of the genus Sporolactobacillus.
\end{abstract}

Sporolactobacillus inulinus is a catalase-negative, spore-forming, homo-fermenting lactic acid bacterium first reported by Kitahara and Suzuki(1). This species has characteristics intermediate between the genus Bacillus and the genus Lactobacillus (2).

We have reported on the morphological, biochemical, and physiological characteristics of spore-forming, lactic acid-producing bacteria including $S$. inulinus comparing with Lactobacillus plantarum, and Bacillus coagulans(2). The strains of those were determined by numerical analysis to be distinct from the type and authentic strains of $B$. coagulans and L. plantarum. The two large clusters were

Address reprint requests to: Dr. M. Kozaki, Department of Agricultural Chemistry, Tokyo University of Agriculture, 1-1, Sakuragaoka 1-chome, Setagaya-ku, Tokyo 156, Japan. 
distinguished by catalase activity and production of acid from lactose and melibiose. However, their classification as spore-forming, lactic acid-producing bacteria was not definitive at the species level. Therefore, DNA-DNA homology studies are needed, not only for the classification at the species level, but also for the evaluation of phenotypic characteristics.

Miller et al. (3) studied the DNA-DNA hybridization between the strains of $L$. plantarum, $S$. inulinus, and B. coagulans and reported that there were no cross reactions among these strains. In 1975, Dellaghio et al.(4) studied the DNA homologies among Lactobacillus species and reported that $S$. inulinus had a low homology index to any of the Lactobacillus species studied. Studies of $16 \mathrm{~S}$ ribosomal RNA cataloguing by Fox et al. (5) showed that $S$. inulinus was distantly related to Bacillus species and to Sporosarcina ureae.

This paper deals with the DNA base composition and the DNA-DNA hybridization of representative spore-forming lactic acid bacteria selected from the strains used in the previous study (2).

\section{MATERIALS AND METHODS}

Bacterial strains. The strains used were Sporolactobacillus inulinus NRIC $1133^{\mathrm{T}}$ (=ATCC $15538=$ JCM 2257) (T=type strain), S. inulinus NRIC 1134 (S-50C, from Prof. O. Kandler, University of Munich, West Germany), and 37 strains of the spore-forming lactic acid bacteria isolated by NAKAYAMA and YANOSHI $(6,7)$ and by AmemiYa and NakAYAma (8). The strains used for comparison were: Bacillus coagulans NRIC $1005^{\mathrm{T}}$ (=ATCC $7050=\mathrm{JCM} 2257$ ), B. coagulans JCM 2258 (=IAM 1194), Bacillus cereus JCM $2152^{\mathrm{T}}$ (=ATCC 14579), Lactobacillus plantarum NRIC $1067^{\mathrm{T}}$ (=ATCC 14917), L. plantarum JCM 1158 (=ATCC 8041), L. plantarum JCM 1151 (=ATCC 10241), and Lactobacillus yamanashiensis subsp. yamanashiensis JCM $1153^{\mathrm{T}}$ (=ATCC 27304). These Lactobacillus strains contain meso-diaminopimelic acid in the cell wall.

Isolation of DNA. Cells grown in GYP medium (2) at $30^{\circ} \mathrm{C}$ were harvested by centrifugation at the late exponential growth phase. Approximately $5 \mathrm{~g}$ of wet cells was used for DNA isolation by the method of SAITO and MiUra (9) with some modifications. Cells of L. yamanashiensis subsp. yamanashiensis, L. plantarum, and $B$. cereus were not lysed by lysozyme alone. In such cases, they were cultured in the medium supplemented with $1.5-5.0 \%$ glycine $(10)$. The cell walls of these strains were lysed by incubation with $\mathrm{N}$-acetyl muramidase SG (11) (Seikagaku Kogyo Co., Tokyo, Japan), Achromopeptidase crude (Wako Pure Chemicals Co., Osaka, Japan), and lysozyme (Seikagaku Kogyo Co.).

Determination of DNA base composition. The DNA base composition was calculated from the denaturation temperature of DNA (Tm) in SSC (SSC: $0.15 \mathrm{~m}$ $\mathrm{NaCl}$ and $15 \mathrm{~mm}$ trisodium citrate, $\mathrm{pH}$ 7.0) using the formula of MARMUR and Doty (12). Tm was determined with a Beckman DU-8 spectrophotometer (Beckman Instruments Inc., Fullerton, Calif., U.S.A.). Calf thymus DNA (Sigma 
Chemical Co., St. Louis, Mo., U.S.A.) was used as a reference, containing $43.0 \mathrm{~mol} \%$ guanine plus cytosine $(\mathrm{G}+\mathrm{C})$.

DNA-DNA hybridization. The SDS-membrane filter method described in previous reports $(13,14)$ was used for DNA-DNA hybridization. DNA was labeled with ${ }^{3} \mathrm{H}$ using a Nick Translation System, $\left[{ }^{3} \mathrm{H}\right]$ - (New England Nuclear, Boston, Mass., U.S.A.). The hybridization reaction was carried out at $60^{\circ} \mathrm{C}$ for $40 \mathrm{hr}$. The radioactivity of the hybrid DNA was measured with a Beckman LS-7800 liquid scintillation spectrometer.

\section{RESULTS AND DISCUSSION}

\section{DNA base composition}

Values of the DNA base composition are shown in Tables 1, 2, and 3. The DNA base composition of the strains of spore-forming lactic acid bacteria, including $S$. inulinus NRIC $1133^{\mathrm{T}}$, ranged from 42.4 to $50.2 \mathrm{~mol}^{\mathrm{o}} \%$ guanine plus cytosine $(\mathrm{G}+\mathrm{C})$. B. coagulans NRIC $1005^{\mathrm{T}}$ and "B. laevolacticus" $\mathrm{M}-39$ had higher percentages -48.3 to $49.1 \mathrm{~mol}^{\%}$. SUZUKI and KiTAHARA (15), using paper chromatography, reported that the DNA base composition of the type strain of $S$. inulinus was $39.3 \mathrm{~mol}^{\circ} \%$. But MiLler et al. (16) found a higher percentage $-47.3 \mathrm{~mol}^{\circ} \%$ $\mathrm{G}+\mathrm{C}$. Our results $\left(47.0 \mathrm{~mol}^{\%} \% \mathrm{G}+\mathrm{C}\right)$ agreed with the value given by MiLlen et al. (16)

\section{DNA-DNA hybridization}

Table 1 shows the results of DNA-DNA hybridization between $S$. inulinus NRIC $1133^{\mathrm{T}}$ and strains in the genera Bacillus and Lactobacillus. When $S$. inulinus

Table 1. DNA-DNA homologies among strains of Sporolactobacillus, Bacillus, and Lactobacillus.

\begin{tabular}{|c|c|c|c|c|}
\hline & \multirow[b]{2}{*}{ Strain } & \multirow[b]{2}{*}{$\begin{array}{c}\mathrm{G}+\mathrm{C} \text { content } \\
(\mathrm{mol} \%)\end{array}$} & \multicolumn{2}{|c|}{ Labeled DNA from } \\
\hline & & & $\begin{array}{l}\text { S. inulinus } \\
\text { NRIC } 1133^{\mathrm{T}}\end{array}$ & $\begin{array}{l}\text { B. coagulans } \\
\text { NRIC } 1005^{\mathrm{T}}\end{array}$ \\
\hline S. inulinus & NRIC $1133^{\mathrm{T}}$ & 47.0 & 100 & 6 \\
\hline B. coagulans & $\begin{array}{l}\text { NRIC } 1005^{\mathrm{T}} \\
\mathrm{JCM} 2258\end{array}$ & $\begin{array}{l}49.1 \\
49.1\end{array}$ & $\begin{array}{l}3 \\
4\end{array}$ & $\begin{array}{r}100 \\
62\end{array}$ \\
\hline B. cereus & $\mathrm{JCM} 2152^{\mathrm{T}}$ & 35.6 & 3 & 3 \\
\hline L. plantarum & $\begin{array}{l}\text { NRIC } 1067^{\mathrm{T}} \\
\text { JCM } 1551 \\
\text { JCM } 1558\end{array}$ & $\begin{array}{l}45.8 \\
45.5 \\
47.5\end{array}$ & $\begin{array}{l}5 \\
2 \\
2\end{array}$ & $\begin{array}{l}3 \\
2 \\
3\end{array}$ \\
\hline \multicolumn{5}{|c|}{$\begin{array}{l}\text { L. yamanashiensis subsp. } \\
\text { yamanashiensis }\end{array}$} \\
\hline
\end{tabular}


Table 2. DNA-DNA homologies among strains of Sporolactobacillus and related organisms.

\begin{tabular}{|c|c|c|c|c|}
\hline \multirow[b]{2}{*}{ Strain } & \multirow[b]{2}{*}{$\begin{array}{c}\mathrm{G}+\mathrm{C} \text { content } \\
\left(\mathrm{mol}^{\circ} \mathrm{o}\right)\end{array}$} & \multicolumn{3}{|c|}{ Labeled DNA from } \\
\hline & & $\begin{array}{l}\text { S. inulinus } \\
\text { NRIC } 1133^{\mathrm{T}}\end{array}$ & $\begin{array}{l}\text { "S. laevas" } \\
\text { M-19 }\end{array}$ & $\begin{array}{c}\text { "B. laevolacticus" } \\
\text { M-8 }\end{array}$ \\
\hline \multicolumn{5}{|l|}{ S. inulinus } \\
\hline NRIC $1133^{\top}$ & 47.0 & 100 & 22 & 27 \\
\hline NRIC 1134 & 46.8 & 88 & 15 & 20 \\
\hline \multicolumn{5}{|l|}{ "S. racemicus" } \\
\hline M-11 & 45.3 & 27 & 35 & 43 \\
\hline \multicolumn{5}{|l|}{ "S. laevas" } \\
\hline M-18 & 42.4 & 22 & 101 & 30 \\
\hline M-19 & 46.2 & 22 & 100 & 33 \\
\hline M-87 & 44.5 & 32 & 23 & 56 \\
\hline \multicolumn{5}{|c|}{ "S. laevas var. intermedius" } \\
\hline M-86 & 50.2 & 84 & 19 & 26 \\
\hline M-103 & 47.4 & 31 & 21 & 54 \\
\hline \multicolumn{5}{|l|}{ "S. laevolacticus" } \\
\hline M-8 & 44.7 & 21 & 23 & 100 \\
\hline M-1 & 43.9 & 24 & 33 & 39 \\
\hline M-7 & 44.7 & 21 & 29 & 41 \\
\hline \multicolumn{5}{|l|}{ "B. racemilacticus" } \\
\hline M-14 & 44.5 & 19 & 29 & 34 \\
\hline M-39 & 48.3 & 6 & 5 & 8 \\
\hline \multicolumn{5}{|l|}{ B. coagulans } \\
\hline NRIC $1005^{\mathrm{T}}$ & 49.1 & 5 & 6 & 8 \\
\hline JCM 2258 & 49.1 & 7 & 5 & 6 \\
\hline \multicolumn{5}{|l|}{ B. cereus } \\
\hline JCM $2152^{\mathrm{T}}$ & 35.6 & 6 & 6 & 7 \\
\hline \multicolumn{5}{|l|}{ L. plantarum } \\
\hline NRIC $1067^{\mathrm{T}}$ & 45.8 & 4 & 4 & 6 \\
\hline \multicolumn{5}{|c|}{ L. yamanashiensis subsp. yamanashiensis } \\
\hline $\mathrm{JCM} 1153^{\mathrm{T}}$ & 37.2 & 4 & 5 & 5 \\
\hline Calf thymus & 43.0 & 0 & 1 & 2 \\
\hline
\end{tabular}

NRIC $1133^{\mathrm{T}}$ was used as a reference, the homology indexes to four strains of the Lactobacillus species ranged from 1 to $5 \%$ and from 3 to $4 \%$ to three strains of the Bacillus species. When B. coagulans NRIC $1005^{\mathrm{T}}$ was used as a reference, the homology indexes were $6 \%$ to $S$. inulinus NRIC $1133^{\mathrm{T}}$ and from 2 to $3 \%$ to four strains of the Lactobacillus species and another Bacillus species. These results indicate that there is little DNA homology between $S$. inulinus and either $B$. coagulans or L. plantarum. 
Table 2 shows the results of DNA-DNA hybridization of the strains of $S$. inulinus with some strains of the "B. laevolacticus," "B. racemilacticus," "S. laevas," "S. laevas var. intermedius," "S. racemicus." S. inulinus NRIC 1134 and "S. laevas var. intermedius" M-86 were highly homologous to $S$. inulinus NRIC $1133^{\mathrm{T}}$. "S. laevas" M-19 was highly homologous to "S. laevas" M-18, and only slightly homologous to "S. laevas" M-87. The reference strains used here showed moderately higher homology values to the strains of S. inulinus (NRIC $1133^{\mathrm{T}}$ and NRIC 1134), "S. laevas" (M-18, M-19, and M-87), "S. laevas var. intermedius" (M-103), "S. racemicus" (M-11), "B. laevolacticus" (M-1, M-7, and M-8), "B. racemilacticus" (M14), and low values to the strains of $L$. plantarum and L. yamanashiensis subsp. yamanashiensis, B. coagulans, and $B$. cereus. These strains, except " $B$. racemilacticus" M-39, are considered to be closer to $S$. inulinus than to the Bacillus and Lactobacillus species. "B. racemilacticus" M-39 showed extremely low homology values to the three references. This strain was identified as $B$. coagulans in a previous paper (2).

Table 3 shows the results of DNA-DNA hybridization among the strains of $S$. inulinus, "S. laevas," "S. laevas var. intermedius," and "S. racemicus." The DNA homology divided them into five groups. The strains in these groups are discussed below in connection with their phenotypic characteristics (2).

Group 1: This group comprises the three strains, S. inulinus NRIC $1133^{\mathrm{T}}, S$. inulinus NRIC 1134, and "S. laevas var. intermedius" M-86. These strains showed extremely high homology to each other, and "S. laevas var. intermedius" M-86 was identified as $S$. inulinus. This group is characterized by an inability to produce acid from galactose, lactose, and melibiose (2).

Group 2: This group comprises fifteen strains of "S. laevas" (12 strains) and "S. laevas var. intermedius" (3 strains). When "S. laevas" strains (M-114, M-88) were used as references, the homology indexes within the strains of this group ranged from 67 to $101 \%$. The group is characterized by an inability to produce acid from inulin, lactose, and melibiose, and a tolerance of high concentrations of $\mathrm{NaCl}(2)$.

Group 3: This group comprises nine strains of "S. racemicus" (7 strains) and "S. laevas var. intermedius" (2 strains). When "S. racemicus" M-116 was used as a reference, the homology indexes ranged from 55 to $119^{\circ}$. This group is characterized by an ability to produce acid from inulin and a sensitivity to $\mathrm{NaCl}$ (2). Furthermore, the strains do not produce acid from lactose and melibiose.

Group 4: This group comprises four strains. "S. racemicus" $\mathrm{M}-13$ and " $S$. laevas var. intermedius" M-98 showed a high homology index $(91 \%$ and $84 \%$ respectively) to the reference strain "S. racemicus" $M-17$. "S. laevas var. intermedius" M-96 showed a high homology index $(79 \%)$ to the reference strain " $S$. laevas var. intermedius" M-98. The group is characterized by an ability to produce acid from melibiose, lactose, and inulin (2).

Group 5: This group comprises the two strains, "S. laevas" M-18 and " $S$. laevas" M-19. These organisms showed an extremely high homology index of $101 \%$ 
Table 3. DNA homologies among the strains of

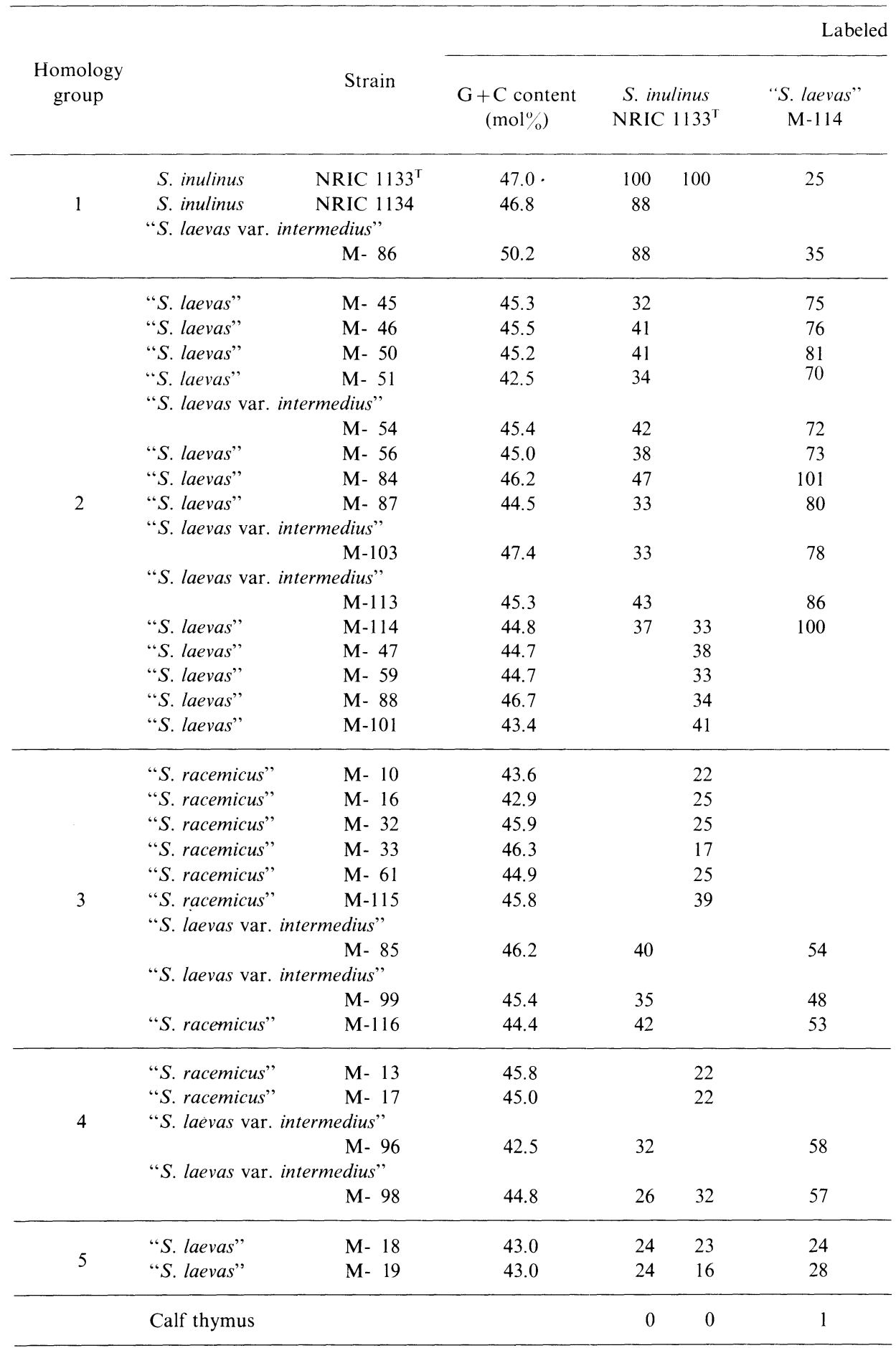


5 groups of spore-forming lactic acid bacteria.

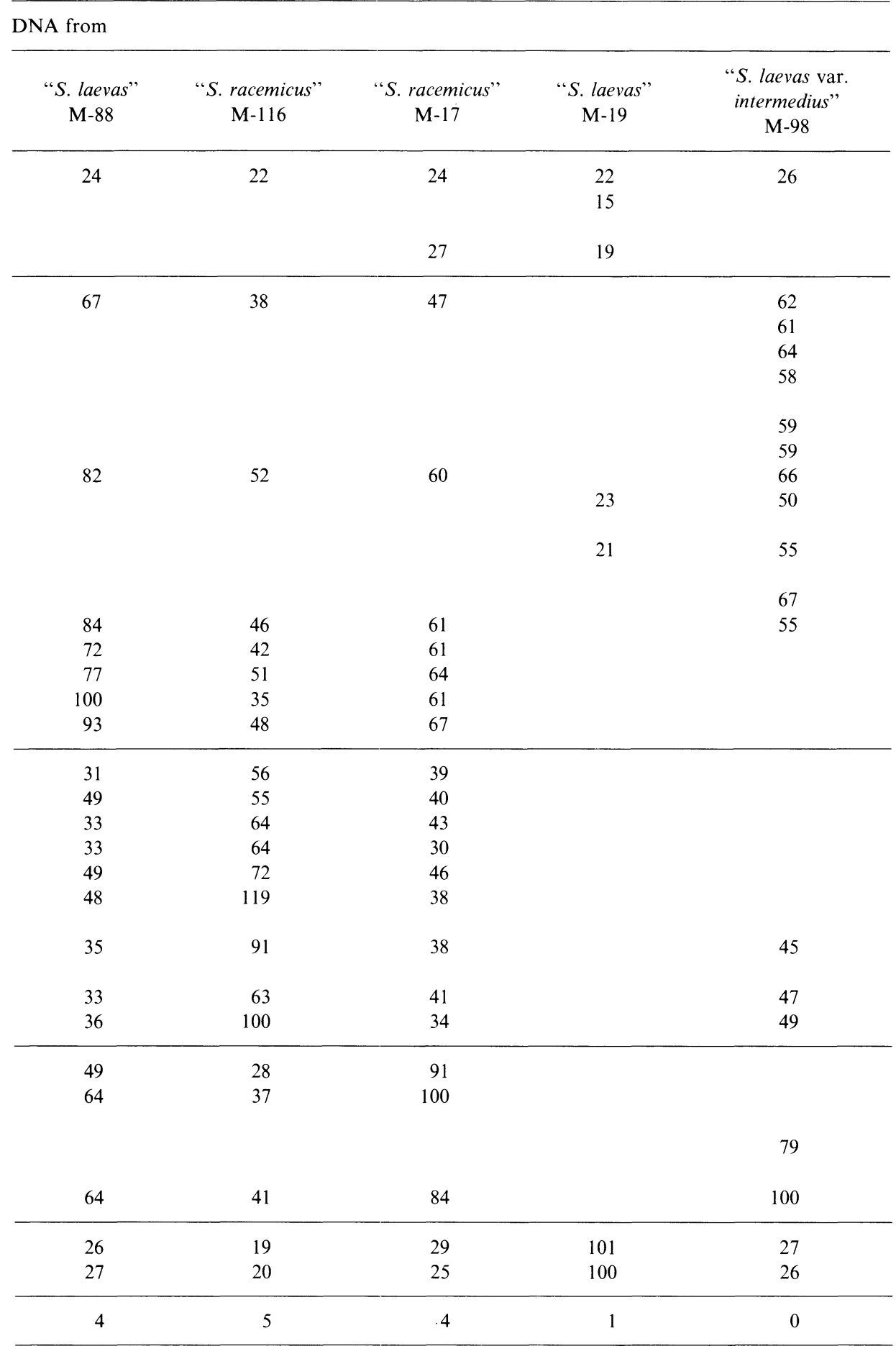


and they showed extremely low homology values to other reference strains.

The strains in these five groups of Sporolactobacillus may be separated into species-presuming groups homogeneous in phenotypic characteristics (2) and DNADNA relatedness.

Isoprenoid quinones and cellular fatty acid composition are considered to be useful for bactrerial taxonomy. UCHIDA and Mogi(17) examined the fatty acid composition of $S$. inulinus, "B. laevolacticus," "B. racemilacticus," "S. laevas," "S. racemicus," and B. coagulans, and found "iso-anteiso-type" of fatty acids in these species, while "unsaturated-type" fatty acids were found in L. plantarum, $L$. yamanashiensis, and L. casei. Other Lactobacillus species $(18,19)$ and the Clostridium species (20) also had "unsaturated-type" fatty acids.

Collins and JONES (21) studied the menaquinone systems of the strains of $S$. inulinus, "B. laevolacticus," "S. laevas," "S. racemicus," and B. coagulans, and found menaquinone with seven-isoprenoid units (MK-7) as a major isoprenoid quinone in these species. These facts indicate that Sporolactobacillus strains are quite different from the strains of Lactobacillus species, and are rather closely related to the genus Bacillus. However, they were distantly related even to the strains of $B$. coagulans, which is considered to be the closest species to Sporolactobacillus among the Bacillus species(17). The Sporolactobacillus strains used in the present study showed moderately high homology to each other.

The present study concludes that the strains named Sporolactobacillus form an independent taxon from the genera Bacillus and Lactobacillus. Sporolactobacillus is likely to be treated as an independent genus belonging to the family Bacillaceae as in Bergey's Manual of Determinative Bacteriology, 8th edition (22).

We thank Dr. O. Nakayama, Yamanashi University, Kofu, for kindly supplying cultures and also for valuable comments. We also thank Dr. K. Yamasato, Institute of Applied Microbiology, The University of Tokyo, Tokyo, for supplying cultures.

\section{REFERENCES}

1) K. Kitahara and J. Suzuki, J. Gen. Appl. Microbiol., 9, 59 (1963).

2) F. Yanagida, K. Suzuki, T. Kaneko, M. Kozaki, and K. Komagata, J. Gen. Appl. Microbiol., 33, 33 (1987).

3) A. Miller, W. E. Sandine, and P. R. Elliker, Can. J. Microbiol., 17, 625 (1971).

4) F. Dellaghio, V. Bottozzi, and M. Vescova, Int. J. Syst. Bacteriol., 25, 160 (1975).

5) G. E. Fox, K. R. Pechman, and C. R. Woese, Int. J. Syst. Bacteriol., 27, 44 (1977).

6) O. Nakayama and M. Yanoshi, J. Gen. Appl. Microbiol., 13, 139 (1967).

7) O. Nakayama and M. Yanoshi, J. Gen. Appl. Microbiol., 13, 155 (1967).

8) Y. Amemiya and O. Nakayama, J. Gen. Appl. Microbiol., 26, 159 (1980).

9) H. Saito and K. Miura, Biochim. Biophys. Acta, 72, 619 (1963).

10) K. Yamada and K. Komagata, J. Gen. Appl. Microbiol., 16, 215 (1970).

11) K. Yokogawa, S. Kawata, T. Takemura, and Y. Yoshimura, Agric. Biol. Chem., 39, 1533 (1975).

12) J. Marmur and P. Doty, J. Mol. Biol., 5, 109 (1962).

13) K. Suzuki, T. Kaneko, and K. Komagata, Int. J. Syst. Bacteriol., 31, 131 (1981).

14) S. Ikemoto, K. Suzuki, T. Kaneko, and K. Komagata, Int. J. Syst. Bacteriol., 30, 437 (1980). 
15) J. Suzuki and K. Kitahara, J. Gen. Appl. Microbiol., 10, 305 (1964).

16) A. Miller, W. E. Sandine, and P. R. E. Elliker, J. Bacteriol., 102, 278 (1970).

17) K. Uchida and K. Mogi, J. Gen. Appl. Microbiol., 19, 129 (1973).

18) J. H. VeERKAMP, J. Bacteriol., 108. 861 (1971).

19) K. Uchida and K. Mogi, J. Gen. Appl. Microbiol., 18, 109 (1972).

20) C. W. Moss and V. J. Lewis, Appl. Microbiol., 15, 390 (1967).

21) M. D. Collins and D. Jones, J. Appl. Bacteriol., 47, 293 (1979).

22) K. Kitahara, In Bergey's Manual of Determinative Bacteriology, 8th ed., ed. by R. E. Buchanan and N. E. Gibbons, The Williams \& Wilkins Co., Baltimore (1974), p. 550. 